\title{
FENNTARTHATÓ TURIZMUS
}

\author{
Varga Zoltán - Csákvári Tímea
}

\section{Összefoglalás}

A turisták megjelenése anyagilag és kulturálisan fellenditi a településeket. Beindul a kereskedelem és a vendéglátás, felfelé mennek az ingatlanok árai, szaporodnak a munkalehetöségek, igy lesz lehetöség a településfejlesztésre. Sok esetben a természeti értékeket csak azzal az indokkal lehet megmenteni, hogy turisztikai látványosságot jelentenek, így az eszmei értéket anyagi értékként beállitva könnyebb elfogadtatni a társadalomban. Sokszor a természeti értékek megóvása helyett azok kirablását tapasztaljuk, ami jelentös környezetszennyezést von maga után.

Sokan szeretnének a turizmusból eredö bevételekböl megélni, és reménykednek, hogy fellenditik a település életét. Kétségtelen, hogy a turizmusnak vannak pozitiv hatásai, de nem hagyhatjuk figyelmen kivül a negativ hatásokat sem. A turizmus sokféleképpen terheli a környezetet, gondoljunk csak a közlekedésre vagy az eldobált hulladékokra, fóleg a fém-és müanyag hulladékra. A turisták közvetlenül is szennyezik a vizet, például a napolaj használatával, motorcsónakokkal, fáradt olajjal, melyet a természetes vizekbe engednek, aminek beláthatatlan következményei lesznek.

Az utóbbi évtizedben nagy hangsúlyt kap a fenntartható turizmus szervezése és fejlesztése. A globalizáció, a technika fejlödése, a turizmus páratlan fejlödési üteme arra készteti az érintetteket, hogy a terület összes szereplöjét bevonva mindenki érdekében figyeljék a fejlödés irányait, ütemét és még idöben tudjanak cselekedni, hogy az adott turisztikai attrakció, szolgáltatás, desztináció a következö generációk számára is úgy legyen elérhetö, ahogy azokhoz a jelen generációk hozzáfértek. A fejlesztés továbbgondolása az eredeti helyzet, állapot felmérésével kellene, hogy kezdödjön. Sokszor akkor történik az elsö beavatkozás, amikor már nyilvánvaló a gyakran visszafordithatatlan károsodás. Fontos továbbá az adott területen megjelenö összes szereplö cselekvésének megfelelö koordinálása. A témában érintettek sora szinte végtelen: érdekeltek pl. a légitársaságok, utazási irodák, öslakosok, helyi lakosok, biztositók, klinikák, természetvédök, de még az egyes turisták is. A fenntartható turizmus kérdése nem csak helyi probléma, az „overtourism” jelensége egyre több világvárost és mindig újabb, "felkapott" régiókat veszélyeztet.

Kulcsszavak: fenntarthatóság, fejlödés, overtourism, turizmus JEL: J10 


\title{
SUSTAINABLE TURISM
}

\begin{abstract}
The appearance of tourists boosts the settlements financially and culturally. Trade and hospitality will start, real estate prices will go up, job opportunities will increase, so there will be opportunities for settlement development. In many cases, natural values can only be saved on the grounds that they are a tourist attraction, making it easier for society to accept an ideological value as a material value. Many times, instead of preserving natural values, we experience their looting, which leads to significant environmental pollution.

Over the past decade, the organization and development of sustainable tourism has received a great deal of emphasis. Globalization, technological advances, and the unparalleled pace of development in tourism are forcing players to engage with all players in the area to keep track of developments, pace, and act in time for the next tourist attraction, service, destination for future generations and be accessed as accessed by current generations. Further development should start with an assessment of the original situation. Often the first intervention occurs when the irreversible damage is already apparent. It is also important to coordinate properly the actions of all actors in the area. The range of subjects involved is almost endless: airlines, travel agents, natives, locals, insurance companies, clinics, conservationists, and even individual tourists. The issue of sustainable tourism is not only a local issue, but the phenomenon of overtourism is threatening more and more cities and newer "upscale" regions.
\end{abstract}

Keywords: sustainability, development, overtourism, tourism JEL: J10 


\section{Bevezetés és irodalmi áttekintés}

Világszerte egyre több ember engedheti meg magának, hogy szabadidejét igényesen, tartalmasan töltse el. Ennek egyik legkedveltebb módja az utazás, ahol lehetőség van a közvetlen élményszerzésre, kikapcsolódásra, pihenésre, feltöltődésre. Az utazást mint szabadidős tevékenységet támogatja a napjainkban divatos egészséges életmódra való törekvés, az információszerzés sokcsatornás lehetősége, az utazási lehetőségek bővülése, az úti célok palettájának szélesedése, az információrobbanás, az igény és lehetőség a tudásszerzésre, valamint a jelenkori tudatformáló trendek.

Az elmúlt években óriási lendület volt tapasztalható a világturizmus fejlődésében, és az előjelzések szerint ez a rapid növekedés az elkövetkező években, évtizedekben is tovább folytatódik. A nagyarányú növekedés leginkább 2000-től figyelhető meg, amikor a kínai turisták is bekapcsolódtak a világturizmus forgalmába, és arányszámuk várhatóan együtt növekszik az egyéb országokból származó turisták számának növekedésével.

A forgalom növekedése egyrészt örvendetes tény, hiszen emberek milliói jutnak páratlan emlékekhez az adott desztinációkban megélt, megtapasztalt élmények által. A reklám, a jó marketing és a világháló adta lehetőségek által az egyre nagyobb számú, jó anyagiakkal rendelkező potenciális turista figyelme könnyen ráirányítható az éppen aktuális nevezetességek, turistacélpontok felfedezésére.

Az utazni, turistáskodni vágyó tömegeket kiszolgálni kívánó háttéripar azonban - legyen szó akár szállításról, elszállásolásról, élelmezésről, idegenvezetésről, mentésről - egyre nagyobb gondban van a megnövekedett számú turisták igényeinek minőségi színvonalon való kielégítésében. Mindehhez hozzájárulnak a, bár áttételesen, de mégis jelentős súllyal érvényesülő gazdasági, társadalmi, környezeti és kulturális dimenziók is. A turizmus eltömegesedésének jelensége a felszínen látható problémák közül leginkább az adott desztináció környezetszennyezését és a helyi lakosság nyugalmának folytonos zavarását jelenti.

A világ turistaforgalmának jelen korunkban bekövetkezett robbanásszerü fejlődését illetően talán az alábbi témák foglalkoztatják leginkább a szakembereket: a „fenntartható turizmus” és az „overtourism” kérdése. Mivel nagyon friss és gyorsan változó jelenségről van szó, így a témákat illető szakirodalomnak sincs hosszú múltja, annak ellenére, hogy nap mint nap rengeteg dokumentum, elemzés és egyéb írás jelenik meg.

\section{Anyag és módszer}

A fenntartható fejlődés kérdése mintegy 300 éve foglalkoztatja az emberiséget, de komoly vizsgálata, beható elemzése, a probléma alapján történő tervezés (elsősorban a gazdaság, társadalom és környezetvédelem területén, amihez később társult a szociokulturális dimenzió is) mintegy rövidnek tűnő, de annál intenzívebb 40 évre 
tehető. A fenntartható turizmus kérdése pedig még ennél is rövidebb, 1-2 évtizedes múltra tekint vissza, bár már korábban is voltak jelek arra, hogy a (tömeg)turizmust valamiféle ésszerü mederbe kell terelni ahhoz, hogy az egyes célpontok látnivalói ne szenvedjenek maradandó károsodást a turisták által. Például a lascaux-i barlangot 1961-ben le kellett zárni, mert a látogatók miatt megváltozott a barlang klímája, és a falon lévő rajzok kezdtek tönkremenni, vagy bizonyos cseppkőbarlangokat részben vagy egészben le kellett zárni, mert a látogatók letördelték a cseppköveket.

A fenntartható turizmus kérdése talán minden, eddig fenntartható fejlődéssel foglalkozó részterületnél is bonyolultabb kérdés, hiszen nagyon sok szereplős, gyorsan változó és hihetetlen tempóban fejlődő ágazatról van szó.

A vizsgálat során elsősorban témareleváns dokumentumok statisztikáinak figyelembevételére, valamint turisztikai szaklapokban vagy a médiában megjelent tudósításokra támaszkodtunk. Elsősorban a világturizmus jelenségeire fókuszáltunk, hiszen az sokrétűbb, bővebb információs anyagot nyújt, föként az egyes desztinációk és megoldási javaslatok sokszínűsége terén. Ez azonban nem jelenti azt, hogy Magyarországot nem érintené az „overtourism” jelensége, vagy nem lennénk érdekeltek a fenntartható turizmus fejlesztésében.

A fenntarthatóság egy rendszer hosszú távú fennmaradást biztosító stratégia kialakítását jelenti.

Az elgondolás, a fogalom nem napjainkban született meg, azonban jelen korunkban adódtak azok a problémák, jelenségek, amelyek szükségessé teszik a fenntarthatóság újraértelmezését, átgondolását, kidolgozását, gyakorlását az egyén szintjétől kezdve egészen a globális rendszerekig.

A fenntarthatóságért folytatott harc ugyan már 300 éves, azonban a valódi küzdelem jelen korunkban folytatódik igazán, amikor már sok helyen visszafordíthatatlan károsodások léptek fel. A napjainkig tartó folyamatból csupán néhány jelentős állomást szeretnénk kiemelni:

Az első megfogalmazás a fenntarthatóságot illetően már a 18. sz. elején megtörtént: Hans Carl von Carlowitz az erdők „fenntartható hasznosításáról” (hosszú távon csak annyit lehet elvenni az erdőből, amennyi újra tud nőni) 1713-ban írt. Az ő megfogalmazása akkor kizárólag az erdőgazdálkodásra vonatkozott. (1)

Az 1970-es években kezdődtek a környezetvédelmi mozgalmak világszerte, mert akkorra kezdett nyilvánvalóvá válni, hogy a gazdasági haszon érdekében elpusztítjuk a környezetünket.

1987-ben az ENSZ Bruntland-jelentésében úgy fogalmazta meg a fenntartható fejlődést (sustainable development) ami olyan fejlődési folyamat, ill. szervezési elv, ami „kielégíti a jelen szükségleteit anélkül, hogy csökkentené a jövendő generációk képességét, hogy kielégítsék a saját szükségleteiket”.

A fogalom az 1980-as évek elején jelent meg nemzetközi szinten, a szociális, valamint a környezeti problémák felismerését, ezen problémák gazdasági fejlődés- 
sel összefüggését jelenti. Ezen problémákat nem lehet külön vizsgálni, hanem csak sajátos módon, együttesen megközelítve. A téma általános ismertséget Lester R. Brown 1981-ben megjelent „Building a Sustainable Society” című műve váltotta ki.

2001 júniusában fogadta el az Európai Tanács Göteborgban a Fenntartható Fejlődés Stratégiát, amely egy harmadik dimenziót ad a Lisszaboni folyamatnak. Sajnos ez figyelmen kívül hagyja azt a felismerést, hogy a környezeti, társadalmi és gazdasági kérdések és problémák összefonódnak, és nem lehetséges őket egymással gyakorta ellentmondó külön stratégiákban, külön prioritásrendszerek mellett kezelni. (2)

A fenntartható fejlődéssel kapcsolatban gyakran megjelenik az ökológiai lábnyom fogalma is, ami az erőforrás-menedzselésben és társadalomtervezésben használt érték, amely azt fejezi ki, hogy adott technológiai fejlettség mellett egy emberi társadalomnak milyen mennyiségü földre és vízre van szüksége önmaga fenntartásához és a megtermelt hulladék elnyeléséhez.

A turizmusra vonatkoztatva pl. akkor legnagyobb az ökológiai lábnyomunk, ha repülővel elutazunk Európából Közép-Amerikába, és ott részt veszünk egy kéthetes hajóúton egy óriás üdülőhajón. Legkisebb lehet pl. akkor, ha gyalogtúrára megyünk a hegyekbe és ott környezettudatosan viselkedünk.

A fenntarthatóság dimenziói: a környezet, a gazdaság, a társadalom, és napjainkban a kultúrát vagy szociokulturális dimenziót is fegyelembe szokták venni. Mindezen dimenziók meghatározók természetesen a fenntartható turizmus tervezésében is.

A tömegturizmus pozitív és negatív hatásainak feltárása és elemzése során is ezen tényezők mentén folynak napjainkban a kutatások, az egymást átszövő, sokszor bonyolult hatások vizsgálata, elemzése és a jövő tervezése.

A gazdasági oldalt tekintve pozitív hatásnak számít elsősorban a helyi lakosság foglalkoztatásának és a helyi gazdasági bevételek növekedésének kérdése, ezáltal pedig a helybeliek életminőségének javulása is. Mindezen túl természetesen a régió is és az adott ország is profitál a turistaforgalom növekedéséből. Negatív gazdasági hatás lehet helyben a megélhetési költségek emelkedése, vagy ha a nyereséget nem kellö mértékben vagy egyáltalán nem forgatják vissza a helyi gazdaságba, adekvát fejlesztésekbe.

A WTO a fenntartható turizmus fogalmát az alábbiak szerint határozza meg:

„Az a turizmus, amely teljes mértékben figyelembe veszi a jelenlegi és jövőbeli gazdasági, társadalmi és környezeti hatásokat, valamint a turisták, az iparág, a környezet és a befogadó közösségek igényeit.”

A WTO fenntartható turizmussal kapcsolatos céljai között szerepel:

„Az összes erőforrás olyan kezelése, amellyel a gazdasági, társadalmi és esztétikai szükségletek kielégíthetők, miközben megmaradnak a kulturális integritás, a fö ökológiai folyamatok, a biológiai sokszínüség és az életfenntartás rendszerei." 
„A fenntarthatóság elvei vonatkoznak a turizmusfejlesztés környezeti, gazdasági és szociokulturális aspektusaira, és a fenntartható egyensúlyt meg kell teremteni e 3 dimenzió között, és garantálni kell ennek hosszú távú fenntarthatóságát." (4) 2017 a fejlesztési célú fenntartható turizmus nemzetközi éve volt (ENSZ). A koordinátor az ENSZ Turisztikai Világszervezete (UNWTO) volt.

Az alábbi 5 kulcsterületet jelölték ki:

- inkluzív és fenntartható gazdasági növekedés

- $\quad$ széles körü társadalmi részvétel, a foglalkoztatottság növelése, a szegénység csökkentése

- erőforrás-hatékonyság, környezetvédelem és klímaváltozás

- kulturális értékek, sokszínűség és örökség

- kölcsönös megértés, béke és biztonság.

Az elmúlt években több világ- és régiós konferenciát rendeztek a fenntartható turizmus témájában. Pl. 2019. június 6. Barcelona: Facing Overtourism: Callanges to Sustainability, Tourist's Experiences \& Local Communities, 2019. június 26-29. Puglia: Between Overtourism and Undertourism, 2019. október 25-26. Hokkaido: G 20 Tourism Ministers' Meeting.

\section{Eredmények és értékelésük}

A világturizmusban az ENSZ Turizmus Világszövetsége szerint 2018-ban mintegy 1,4 milliárd ember vett részt, beleszámítva a hivatalos utazásokat és az ismételt utazásokat is. Ez a szám 6\%-kal nagyobb, mint a megelőző évben. Az emelkedés évről évre töretlen, és az előrejelzések szerint a jövőben is folyamatos emelkedés várható. A fogadóhelyek befogadóképessége véges, a várakozási idő a beléptetőhelyeken, múzeumokban vagy bármely turistákat kiszolgáló helyszínen (bolt, étterem, mosdó, sílift stb.) a végtelenbe nyúlik, ami időt rabló és megterheli, frusztrálja a vendéget, de a fogadóhely szakembereit és lakosait is. Az eltömegesedés, „túlturistásodás” jelensége veszélyezteti a turizmus fenntarthatóságát, a környezetünk, bolygónk épségét, a kiegyensúlyozott, minőségi turizmust is, ami végső soron leginkább a vendéglátó és vendég elégedettségével mérhető. 


\section{Leglátogatottabb uticélok (millió fô)}

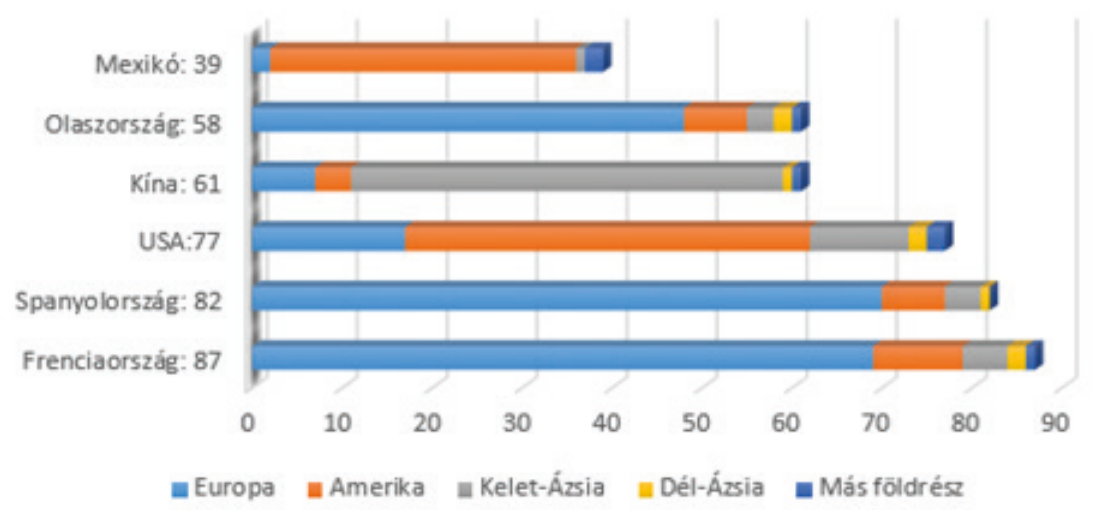

1. ábra: A leglátogatottabb desztinációk 2018-ban a küldő régiókat tekintve.

Forrás: Grafik: ORF.at; Quelle: theguardian.com/World Tourism Organisation

Az ábráról leolvasható, hogy az 5 leginkább látogatott ország közül 3 Európában van, valamint a legaktívabb küldőrégió Európa, ezt követi Amerika, sorrendben a harmadik pedig Kelet-Ázsia.

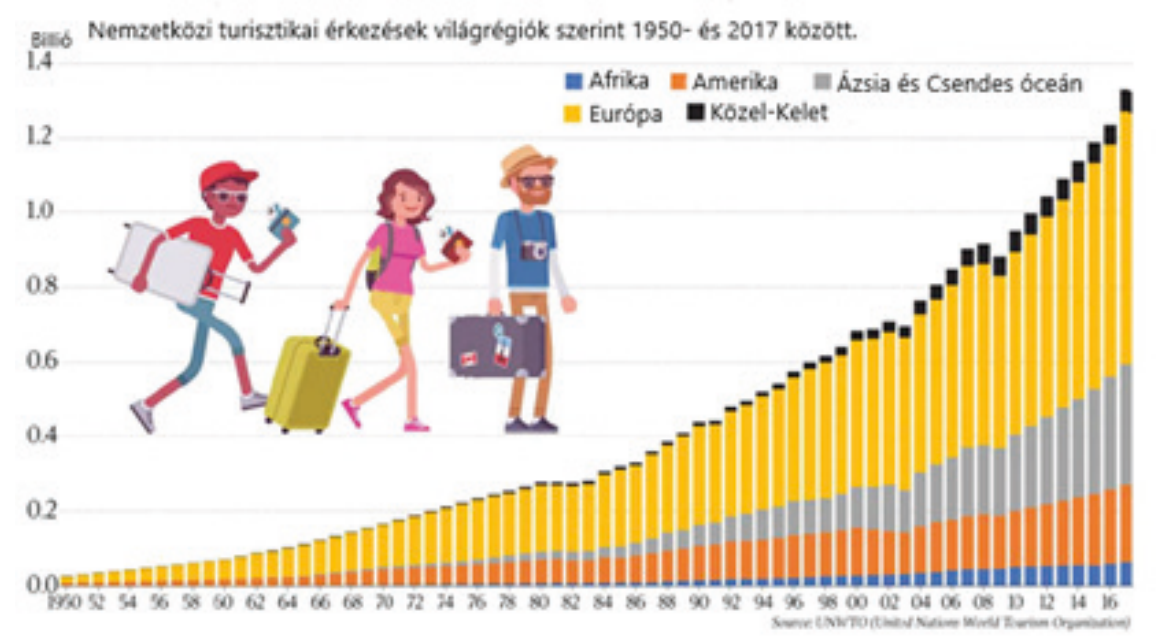

2. ábra: Turistaérkezések növekedése földrészenként 1950 és 2017 közt

Forrás: UNWTO

Az ábra szemléletesen mutatja, hogy a világturizmus 1950-től fogva egyfolytában fejlődik, az utazók száma egyenletesen emelkedik. Azonban az emelkedés kezdetben, egészen a 80-as évekig, mérsékelt, aztán egyre meredekebb. Minden ábrázolt kon- 
tinens esetén megfigyelhető az utazók számának az emelkedése, de legintenzívebb az európai turisták esetén. 1980-tól az ázsiai turisták számának emelkedése is jelentős.

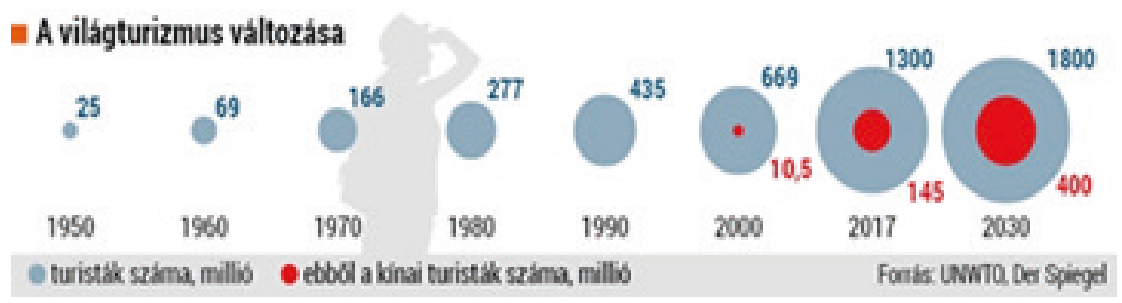

3. ábra: A világturizmus tényleges és várható változása 1950-2030 között. Forrás: UNWTO, Der Spiegel

1990-től figyelhető meg a turizmus dinamikus, sok tekintetben túlzott mértékű fejlődése. A 2030-ig vázolt prognózis még ennél is sokkal nagyobb arányú növekedést vetít előre. Bizonyos városok, egyéb úti célok már most is küzdenek az „overtourism” jelenségével.

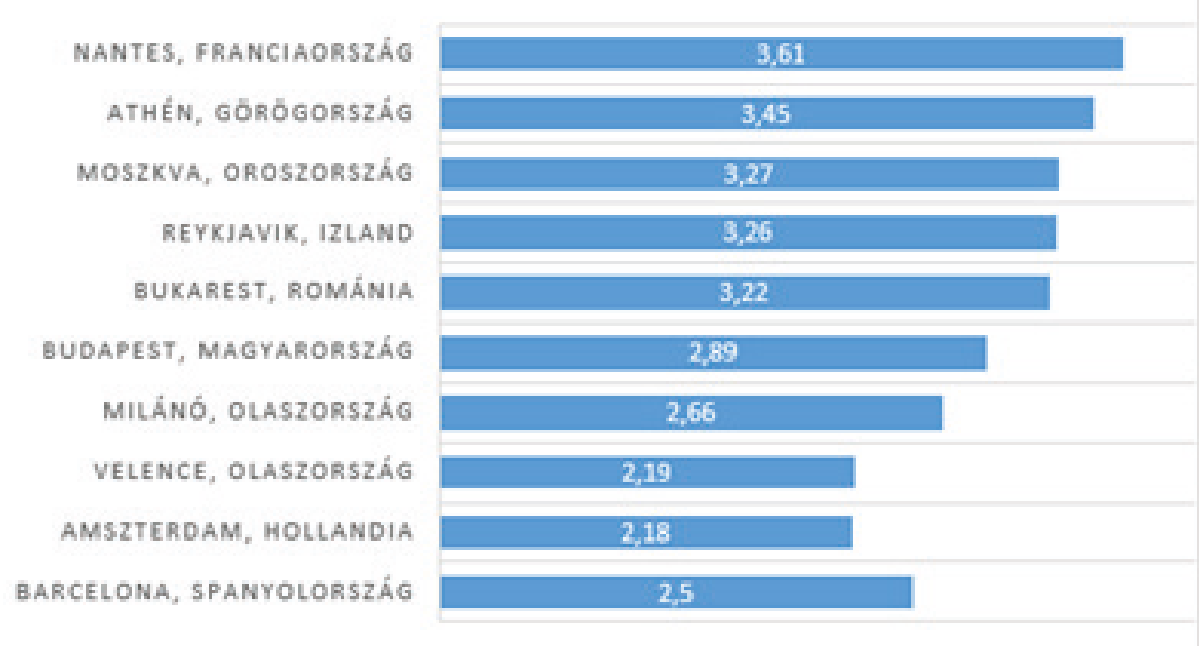

\section{4. ábra: A „túlturistásodás” által leginkább veszélyeztetett városok. \\ Forrás: TravelBird + Statista 2018}

A 4. ábra által bemutatott európai városok közül, amelyeket különösen fenyeget a „túlturistásodás”, Budapest az 5 . helyen áll a rangsorban. A város kedveltsége leginkább a sok látnivalónak, az alkalmas földrajzi fekvésnek, kultúránknak, gasztronómiánknak és a jó légiközlekedésnek köszönhető. Az ún. „bulinegyed” turistaforgalma növekedett az elmúlt évtizedben különösen, leginkább az angol turisták érkeztek nagy számban. 


\section{$\mathrm{Az}$,overtourism” jelensége}

A „túlturistásodás” („overtourism”) „olyan turistacélpontok, ahol a vendéglátók, a vendégek, a helyiek vagy a látogatók úgy érzik, túl sok a látogató, és az életminőség a környéken vagy az élmény elfogadhatatlan mértékben leromlott." (Felelős Turizmus Partnerség) (9)

A „túlturistásodás” vonatkozhat egyaránt természeti vagy kulturális látványosságra, de akár városra is. Bizonyos városokat (akár kisvárost, mint pl. Velence, Dubrovnik, de akár nagyvárosokat is, pl. Barcelona, Amszterdam) érinthet a világ bármely pontjáról érkező turisták tömegeinek megjelenése, akik leginkább repülővel - gyakran charterjáratokkal - vagy óriási üdülőhajókkal érkeznek. Amennyiben a célpont autósztrádán is - vagy csak azon és/vagy közúton - megközelíthető, akkor az autóbuszos turizmus (is) óriási mértékben megnövekszik, pl. Hallstatt vagy Velence esetében.

A probléma akkor keletkezik, ha a helyi lakosság számához mérten irreális mértékben megnövekszik a turisták száma, és a fogadó terület nem, vagy csak nehezen, esetleg csak alacsony színvonalon tudja kiszolgálni az érkező vendégeket. Hallstatt esetében a település állandó lakosainak száma 850 fó mindösszesen, ezzel szemben majdnem évi egymillió turista érkezik. Ugyanez az arányszám Velence esetében: 55 ezer lakos - majdnem 30 millió turista/év.

Az alábbi hallstatti statisztika azt mutatja, hogy milyen mértékben nőtt a turistabuszok száma januártól decemberig az egyes években. A növekedés óriási: amíg 2010-ben 3440 busz érkezett, addig 2018-ban 19144 volt a turistabuszok száma.

\section{BUSZOK SZÁMA (DB)}

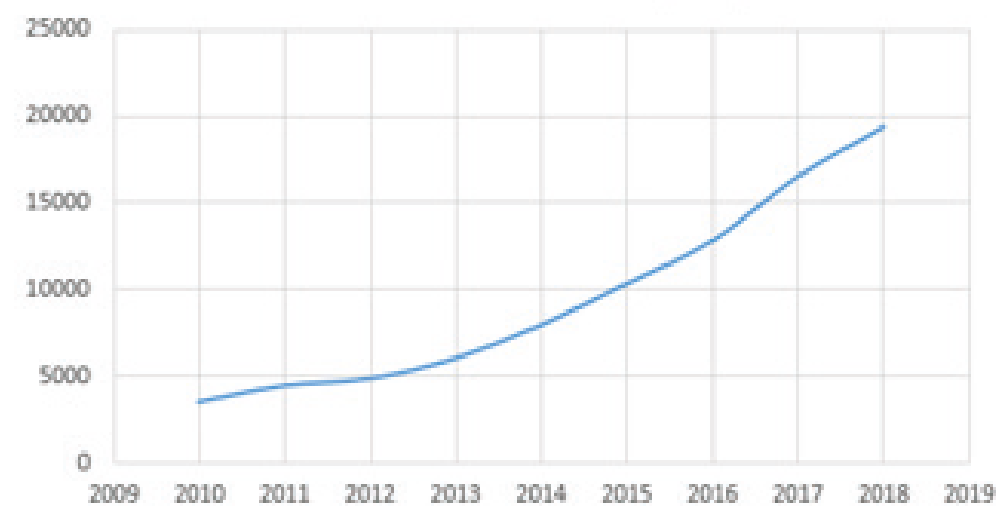

5. ábra: A Hallstattba érkező buszok száma az egyes években

Forrás: https://www. bfhallstatt.at/themen/bustourismus-in-hallstatt/ bustourismus-hallstatt-zablen-fakten/ 


\begin{tabular}{|c|c|c|c|c|c|c|c|c|c|c|}
\hline Megnevezés Êx & 2010 & 2011 & 2012 & 2013 & 2014 & 2015 & 2016 & 2017 & 2018 & 2019 \\
\hline Január & 0 & 0 & 0 & 0 & 180 & 256 & 294 & 544 & 575 & 643 \\
\hline Február & 0 & 0 & 0 & 0 & 234 & 293 & 423 & 556 & 761 & 964 \\
\hline Március & 0 & 0 & 18 & 105 & 309 & 402 & 561 & 802 & 1135 & 1256 \\
\hline Április & 0 & 153 & 322 & 426 & 541 & 700 & 842 & 1155 & 1484 & 1743 \\
\hline Majus & 483 & 634 & 679 & 789 & 941 & 1248 & 1547 & 2024 & 2190 & 2441 \\
\hline Jünùs & 685 & 825 & 861 & 801 & 1104 & 1412 & 1606 & 2041 & 2434 & 2588 \\
\hline Július & 609 & 704 & 707 & 906 & 1008 & 1330 & 1623 & 1757 & 2112 & 2174 \\
\hline Augusztus & 652 & 722 & 792 & 1005 & 1016 & 1325 & 1502 & 1787 & 2122 & 2151 \\
\hline Szeptember & 644 & 791 & 851 & 952 & 984 & 1261 & 1536 & 1899 & 2030 & 2159 \\
\hline Október & 377 & 566 & 587 & 714 & 859 & 1125 & 1410 & 1857 & 2115 & 2316 \\
\hline November & 0 & 0 & 0 & 44 & 342 & 448 & 703 & 1023 & 1205 & 1390 \\
\hline December & 0 & 0 & 0 & 228 & 399 & 501 & 729 & 1050 & 1181 & 1200 \\
\hline Ósszesen & 3450 & 4395 & 4817 & 5970 & 7917 & 10301 & 12776 & 16495 & 19344 & \\
\hline
\end{tabular}

1. táblázat: Buszok száma az egyes években havi bontásban

Forrás: https://www.bfhallstatt.at/themen/bustourismus-in-hallstatt/ bustourismus-hallstatt-zahlen-fakten/

Az 1. számú táblázatból kitünik, hogy a folyamatos növekedés mellett a városka turistaforgalma erős szezonalitást is mutat: a legtöbb turista májustól októberig érkezik.

- Miért indul el egyre több turista?

- Anyagilag egyre többen engedhetik meg maguknak az utazást.

- Népszerű szabadidő-eltöltési formává vált az utazás. („A legjobb kikapcsolódási és élményszerzési lehetőség.")

- Jó reklám és marketing (pl. Plitvice - „Európa legszebb nemzeti parkja”)

- Az attrakció szerepel az UNESCO-listán. (Áldás vagy átok?) Sok utazási iroda szervezi körútjait az UNESCO-listán szereplő attrakciók köré.

- Gyors és kényelmes közlekedési lehetőségek adottak. Közvetlen, gyakori és kényelmes repülőjáratok, autósztrádák, IC-vonatok.

- Technikailag magas színvonalú, gyors és kényelmes járművek: személyautók, buszok, vonatok, repülők.

- Rövidül a munkaidő, növekszik a szabadidő, több idő jut utazásra is.

- Az egészséges életmód szempontjából kiemelt tevékenységnek számít az utazás - testi, lelki, szellemi feltöltődés.

- A turisták/influenszerek által a közösségi oldalakra feltöltött úti fotók/szelfik inspirálnak („ezt nekem is látnom kell, erről én sem maradhatok le”). Ez a jelenség napjainkban nagyon gyakori és nagyon hatásos.

- Bizonyos helyszíneket játékfilmek népszerüsítenek („Klinika a pálmafák alatt”, kínai Hallstatt).

- Az emberek tudásvágya, igény a közvetlen tapasztalatszerzésre.

- Sok utazási kedvezmény: pl. early bird vagy last minute akciók, csoportos vagy korkedvezményes lehetőségek. 
- A kommunikáció és információszerzés gyorsasága. Online jegyrendelés, helyfoglalás, információszerzés (leggyakrabban angol nyelven, ami napjainkban világszerte már egy második anyanyelvnek számít, tehát sokan beszélik).

- A média napi tudósításai bizonyos kedvelt turistacélpontokról, ami felkelti a lakosság figyelmét, és elindulnak a belföldi turisták is, hogy ők se maradjanak le a látványról.

- $\quad \mathrm{Az}$ „overtourism” hozadéka, árnyoldala, negatív következményei

- Környezetszennyezés. Szemetelés, feleslegessé vált holmik helyszínen hagyása.

- A közlekedési eszközök károsanyag-kibocsátásának növekedése. Hatalmas probléma a repülők és óriáshajók által kibocsátott levegő- és élővíz-szennyező káros anyagok hatása. Ez ellen különösen nehéz küzdeni, hiszen sokak számára ez nem látható, nem érzékelhető, nem mérhető, míg pl. a nagyvárosokban közlekedő autók kipufogógázait az ottlakók nap mint nap beszívják, közvetlenül megtapasztalják. Pedig pl. egy repülő egyetlen utasára számítva Magyarországról Közép-Amerikába annyi a repülőgép károsanyag-kibocsátása mint egy középkategóriás autónak egész évben.

- Lárma (pl. partyturisták - budapesti bulinegyed)

- Árfelhajtó hatás: emelkednek a lakásbérleti díjak, az éttermek, de még a piaci termékek árai is.

- Eltűnnek a helyi lakosok és a helyi vendégek, mivel a lárma, a zaj, a tömeg, a megemelkedett árak lehetetlenné teszik megszokott életritmusuk folytatását.

- Napi rutinná válik a sorbanállás mind a helyiek, mind a turisták részéröl.

- A természeti táj átalakul utakká, repülőterekké, parkolókká, egyéb turistákat szolgáló létesítménnyé.

- A szállodák és a turisták rengeteg energiát használnak fel.

- A helyi kultúra átalakul, esetleg meg is szünik, mivel a turisták igényei, szükségletei kerülnek elötérbe.

- Ökológiai rendszerek károsodnak (pl. nem megfelelő vagy nincs szennyvíztisztítás)

- Megszünnek a hagyományos boltok, többnyire csak szuvenírboltok és a turistákat kiszolgáló lokálok nyílnak.

- Megjelenik a kriminalitás: zsebtolvajlás, széplányok futtatása, kábítószerezés stb.

\section{Következtetések, javaslatok}

Nagyon sok, összetett indítéka van a turizmus tömegeket érintő kibővülésének és fejlődésének. A diszkrecionális jövedelem növekedése, a technikai fejlődés (informatika, jármüipar, hírközlés stb.) és a globalizáció létrehozta azt a helyzetet, hogy emberek tömegei elutazhassanak akár évente többször is, akár távolabbi tájakra is. 
A gyors fejlődés pozitív hozadékai mellett megjelennek a tömegturizmus árnyoldalai is. A negatív hatások elkerülése/csökkentése érdekében a legjobb megoldás az előrelátó tervezés és a jó gyakorlat átvétele.

A fapados légitársaságok elterjedése miatt egyre több turista kel útra. 2017-ben 1,3 milliárd turista utazott világszerte az ENSZ Turisztikai Világszervezetének adatai szerint. Az idegenforgalom a világgazdaság jelentős húzóágazatává vált, a globális GDP tizedét adja.

Mivel a turizmusban nagyon sok szereplő vesz részt, roppant gazdasági haszon származik belőle akár az egyes embert, akár közösségeket, országokat tekintünk, nagyon sok érdek és ellenérdek jelenik meg az ágazatban, és ily módon a fenntartható turizmus megteremtésében, folytatásában.

$\mathrm{Az}$ „overtourism” és lehetséges megoldások:

- Világszerte már eddig is sok törekvés tapasztalható a fenntartható turizmus megteremtése érdekében. A cél: élvezhetőbbé tenni az utazásokat, a megbomlott egyensúlyt helyreállítani, és lehetőleg előre tervezni, és nem a már visszafordíthatatlan károsodásokat megpróbálni orvosolni.

- A helyszín teljes lezárása (pl. lascaux-i barlang, vagy az Oluru szikla: 2019. október 26-tól megtiltották (mintegy 150 év után) - első fehér megmászója 1873-ban az angol felfedező William Goose volt - az Ausztráliában található szikla megmászását, mert az az amangu bennszülöttek szent helye. A látogatók száma: az 1950-es években: pár száz, 2019-ben: több mint 400000.

- A helyszín részleges lezárása javításra, bővítésre, fejlesztésre (pl. Inka-ösvény - 1 hónap, Feröer-szigetek - 2 nap). A Feröer-szigeteken a helyreállító, építő- és javítómunkálatokba az önkéntes turistákat is bevonják, és fizetik a 2 napi ellátásukat.

- Belépőjegy bevezetése. Pl. Amszterdamban 2019 januárjától 8 eurós belépődíjat fizetnek az egynapos turisták, Velence is tervezi az egynapos belépődíjak kivetését, 2022-től pedig az előre történő regisztrációt is.

- A belépőjegy árának (drasztikus) emelése. Pl. A comodói sárkánygyíkok védelmében 2020-tól 1000 dolláros (éves „tagsági díj”) lesz az eddigi 20 dolláros belépőjegy helyett - az ökológiai egyensúly megbomlása miatt (2008 - 44 ezer turista, 2018 - 176 ezer turista).

- Elözetes regisztrálási kötelezettség. Ezt már több helyszínen bevezették, pl. a Plitvicei-tavaknál, az Inka- ösvényen. Az előzetes regisztrálási kötelezettség általában azt is jelenti, hogy ha megtelik a napi vagy éves kvóta, akkor annál többen nem regisztrálhatnak. Az előzetes regisztrálás kötelezettségét Velence 2022-től szándékszik bevezetni. Vagy pl. a bécsi adventi vásár szombati és vasárnapi napjain csak bizonyos számú autóbuszt enged be a belvárosba, akiknek szükséges előzetesen regisztrálniuk. 
- Napi látogatók számának korlátozása. Ez általában előzetes regisztrálási kötelezettséggel érhető el. Inka-ösvény: napi 500 fő léphet be (ebből 200 turista, 300 ellátó személyzet).

- Közlekedés racionalizálása (pl. shuttlebuszok). Pl. Luxemburg városban csak a város határáig mehetnek a turistabuszok, onnét shuttlebusz viszi a látogatókat a városközpontba. Vagy Piránban is csak a város előtt szállíthatnak ki a turistabuszok, onnét kisbuszokkal lehet a városközpontig utazni.

- Az infrastrukturális fejlesztés korlátozása. Ez első látásra furcsán hangzik, de a fenntartható turizmus feladata az, hogy ésszerü mederbe terelje a turizmust, az ne váljon parttalanná, vagyis csökkentse a gyakran már szinte invázióvá duzzadt turistaáradatot. Tehát nem építenek újabb szállodákat, parkolót és egyéb turistákat szolgáló létesítményt.

- Az oktatás, nevelés, ismeretterjesztés célirányos fejlesztése. Az iskolai oktatás és a családi nevelés fontos eleme, hogy a gyerekek megtanulják a természettel szembeni felelősségteljes viselkedés szabályait, azokat a gyakorlatban betartsák, és utazásaik során megőrizzék a természeti és kulturális kincseinket.

A fenntartható turizmus megteremtése globális feladat, a világturizmus roppant méretű növekedése megköveteli a cselekvés szükségességét. Gyakori probléma az érdekek ütközése és a túl késői problémafelismerés. Számtalan csúcstalálkozó, konferencia témája az „overtourism”, azonban a feladatok kijelölése, célok, elvek meghatározásán túl nehezen halad a megoldás megtalálása, hiányzik a gyors cselekvés. Az eredmények prezentálása, a jó gyakorlat bemutatása nem olyan hangsúlyos, mint a probléma megfogalmazása. A megoldáskeresésre vannak példák bőven: pl. hasonló problémával küzdő városok fognak össze, hogy közösen dolgozzanak ki stratégiákat, keressenek megoldásokat. A turistaadó vagy belépődíj vagy parkolódíj kivetéséből vagy emeléséből befolyó összeget beforgatják a turizmusba, de oly módon, hogy az adott tevékenységgel csökkentsék a turisták számát.

$\mathrm{Az}$ „overtourism” jelenségére mindenképpen kell találni feloldást, mert ez nemcsak a fogadóterület számára jelent mindennapi terhet, hanem maga a turista is frusztrálttá, fáradttá, elégedetlenné válik a tülekedés, várakozás, sorban állás révén.

\section{Felhasznált irodalom}

[1.] http://www.nachhaltigkeit.info/artikel/nachhaltigkeit_i_d_forstwirtschaft_ 1725.htm letöltve: 2019. december 01.

[2.] https://www.ceeweb.org/hu/eu-sd/ letöltve 2019.11.30. 
[3.] https://felsofokon.hu/kornyezetvedelem/az-okologiai-labnyom-fogalmaszamitasa-lehetoseg-0/ letöltve: 2019. november 30 .

[4.] https://unwto.org/sustainable-development letöltve: 2020.01.20.

[5.] Grafik: ORF.at; Quelle: theguardian.com/World Tourism Organisation letöltve 2019. 11.30.

[6.] UNWTO letöltve 2019. 11.30.

[7.] UNWTO, Der Spiegel letöltve 2019. 11.30.

[8.] TravelBird + Statista 2018 letöltve 2019. 11.30.

[9.] https://index.hu/gazdasag/2019/04/30/a_bulinegyed_lakoi_ugy_erzik_egy_ nagy_kozvece_lett_a_kornyek/ letöltve: 2019.november 30 .

[10.] https:/www.bfhallstatt.at/themen/bustourismus-in-hallstatt/bustourismushallstatt-zahlen-fakten/ letöltve 2019. november. 30 .

[11.] https:/www.bfhallstatt.at/themen/bustourismus-in-hallstatt/bustourismushallstatt-zahlen-fakten/ letöltve: 2019. 12.05.

\section{Szerzők:}

\section{Dr. Varga Zoltán}

adjunktus

Pécsi Tudományegyetem

Egészségtudományi Kar, Zalaegerszeg 8900, Landorhegyi u 33.

zoltan.varga@etk.pte.hu

\section{Csákvári Tímea}

szakoktató

Pécsi Tudományegyetem

Egészségtudományi Kar, Zalaegerszeg 8900, Landorhegyi u 33.

timea.csakvari@etk.pte.hu 